\title{
Omega-3 Yağ Asitlerinin İnsan Sağlığı Üzerine Etkileri
}

\begin{tabular}{l|r}
\hline $\begin{array}{l}\text { Derleme / Review } \\
\text { Geliş Tarihi /Received } \\
\text { 16.06.2017 }\end{array}$ & \\
$\begin{array}{l}\text { Kabul Tarih / Accepted } \\
22.09 .2017\end{array}$ & Şaban ÇELEBI, Hatice KAYA*, Adem KAYA \\
DOI & Atatürk Üniversitesi Ziraat Fakültesi Zootekni Bölümü, Erzurum- Türkiye \\
10.28955/alinterizbd.319437 & *e-posta: hkaraca@atauni.edu.tr \\
ISSN 2564-7814 & \\
e-ISSN 2587-2249 & \\
\hline
\end{tabular}

Öz: Bu derleme çalışması, omega-3 yağ asitlerinin insan sağlığı üzerine olan etkilerini belirlemek için daha önce yapılmış çalışmaların incelenmesi ve konuda bir kanaate ulaşılması amacıyla yapılmışıtır. Bugüne kadar yapılan araştırma sonuçları, omega-3 yağ asitlerinin başta kalp damar hastalıkları ve yüksek tansiyon olmak üzere Alzheimer, depresyon, şizofreni, astım, felç, romatoid artrit, osteoporoz ile prostat, göğüs bağırsak ve akciğer kanseri gibi çok sayıda hastalığın önlenmesi ve tedavisinde hayati bir öneme sahip olduğunu ve herhangi bir yan etkinin bulunmadığını göstermiştir. Keza, bu doğal fonksiyonel bileşiklerin adı geçen hastalıkların önlenmesi ve tedavisinde terettüd etmeden güvenle kullanılabileceği sonucuna varılmıştır.

Anahtar Kelimeler: Omega-3 yağ asidi, insan, sağlık

\section{Effects of Omega-3 Fatty Acids on Human Health}

\begin{abstract}
Omega-3 fatty acids in order to investigate effects on human health, review of previous studies and outlined in this study, the results of previously conducted research on omega-3 fatty acids and mainly cardiovascular disease and hypertension, including Alzheimer, depression, schizophrenia, astima, stroke, rheumatoid arthritis, osteoporosis and prostate, breast, bowel and lung cancer is of vitual importance in the preventation and treatment of of many diseases and showed that no occurance of significant side effects also concluded that this natural functional compounts of the name of results can be used safely in the preventioan and treatment of the aforemetion ed diseases.
\end{abstract}

Keywords: Omega-3 fatty acid, human, health

\section{GİRIŞ}

Sağlıklı bir yaşam, büyüme, fiziksel ve zihinsel fonksiyonların sürekliliği ancak dengeli ve yeterli beslenmeyle mümkün olabilmektedir. Tarihi kaynaklar iyi beslenen milletlerin daima büyük medeniyetler meydana getirdiklerini göstermektedir. Keza iyi beslenen ülkeleri ileri, yeteri kadar beslenmeyenler ise geri kalmış ülkeler olarak sınıflandırılmaktadır (Çelebi ve Karaca, 2006). Besinlerin temel fonksiyonları organizmanın metabolik ihtiyaçları için gerekli olan besin maddelerini sağlamaktır. Oysa besinler organizmanın metabolik aktivitesi için gerekli olan makro ve mikro besin maddelerini sağlamakla birlikte, sağlık üzerine olumlu etkileri olan bazı bileşikleri de içermektedirler. Son yıllarda yapılan bilimsel çalışmalar, sağlık ve hastalıklar arasındaki ilişkiyi açık bir şekilde ortaya koymuş olup, epidemiyolojik çalışmalar, beslenmenin kronik hastalıkların önlenmesindeki rolüne işaret etmektedir. Çalışmaların bazı besin maddelerinin doğal yollardan bazı kronik hastalıkların önlenme ve tedavisindeki etkinliğini ortaya koyması, sağlığımızın korunmasında yeterli, dengeli ve doğru beslenmenin önemini artırmıştır (Coşkun, 2005).

Belirli hastalıklarla beslenme arasındaki ilişkiler araştırılırken en fazla üzerinde durulan ve sorgulanan gıda maddesi yağlar olmuştur. Araştırmalarda özellikle yağ asitlerinin doymuş veya doymamış yapıda olmaları, cis/trans yapıda olmalarının yanında, yağların kolesterol ve esansiyel yağ asidi içerikleri ve oksidatif stabiliteleri üzerinde durulmaktadır. İnsan beslenmesinde önemli role sahip olan yağlar, sadece yüksek enerji kaynağı olmayıp, yağda çözünen vitaminleri, kan lipit düzeyi üzerindeki rolleri ve omega-3 yağ asitleri gibi fonksiyonel bileşikleri içermeleri nedeniyle oldukça önemlidirler (Çakmakçı ve Kahyaoğlu, 2012). 

Bu çalışmada, omega-3 yağ asitlerinin insan metabolizması ve sağlığı üzerine olumlu etkilerine vurgu yapılarak toplumda söz konusu yağ asitlerinin öneminin anlaşılmasına katkı sağlamak amacıyla, konuyla ilgili olarak yürütülmüş olan bilimsel araştırmalar irdelenerek bir sonuca ulaşılmaya çalışılmıştır.

\section{YAĞ ASITLERI}

Hidrojen, karbon ve oksijenden meydana gelen ve organik bir bileşik olan yağlar, içerdikleri yağ asitleriyle birbirlerinden ayrılırlar. Yağların fiziksel, kimyasal ve fizyolojik özellikleri, birinci derecede yapılarındaki yağ asitlerinin cins ve miktarına bağlıdır. Yağ asitlerinin fiziksel, kimyasal ve beslemedeki rolleri; yağ asidi molekülündeki karbon atomu sayısına, yani zincir uzunluğuna, doymuşluk ve doymamışlık derecesine, çift bağ sayısına, çift bağların hangi karbon atomları arasında bulunduğuna ve hidrojenlerin karbon atomuna bağlanma pozisyonuna göre belirlenir (Keha ve Kührevioğlu, 1993; Karaca ve Aytaç, 2007; Balçık 2014). Yağ asitleri iki ila otuzdan fazla karbon atomu içeren ve molekülün bir ucunda metil $\left(\mathrm{CH}_{3}\right)$ grubu diğer ucunda karboksil $(\mathrm{COOH})$ grubu ile iki sonlandırma bölgesi bulunan bir hidro-karbon zincirinden oluşmaktadır. Karbon atomları karboksil ucundan başlanarak numaralandırılırlar. İki ve üç nolu karbon atomları $\alpha$ ve $\beta$ sembolleri ile gösterilirken, zincirin diğer ucundaki metil karbonu omega (n) sembolü ile gösterilir (Brossard ve ark., 1996; Ruxton ve ark.,2005). Karbon atomu sayılarına göre kısa (2-6), orta (6-10), uzun (12-20) ve çok uzun $(>22)$ zincirli olarak isimlendirilen yağ asitleri yapılarında çift bağ içermiyorlarsa doymuş (satüre) çift bağ içeriyorlarsa doymamış (ansatüre) yă̆ asitleri olarak tanımlanırlar. Doymamış yağ asitleri ise çift bağlarının sayısına göre tekli (monoansatüre) ve çoklu doymamış (poliansatüre) yağ asitleri olarak sınıflandırılırlar. Keza, doymamış yă̆ asitleri ilk çift bağın bulunduğu omega karbonuna göre de n-3, n-6, n-7 ve n-9 gibi isimler alırlar. Çift bağın yeri $\Delta$ sembolünün üzerine yazılan rakamlarla ifade edilir. Yapıya çift bağın katılmasını sağlaya desatürazlar çift bağın karbonlara eklendiği karbona göre $\Delta^{4}, \Delta^{5}, \Delta^{6}$ veya $\Delta^{9}$ - desatüraz olarak tanımlanır. Çift bağların ucundaki karbonlara bağlı hidrojen atomlarının yerleşimine göre de yağ asitlerinin cis ve tans olmak üzere iki geometrik izomeri bulunur. Mesela, cis- $\Delta^{9}$, yağ asidinin 9 ve 10 nolu karbon atomları arasında bir cisçift bağ Çoklu doymamış yağ asitlerindeki a:b şeklindeki ifade de a: karbon sayısını, b: çift bağ sayısını n: metil karbonuna en yakın çift bağın pozisyonunu gösterir (C18:2 n-6) (Das, 2006; Konukoğlu, 2008). 


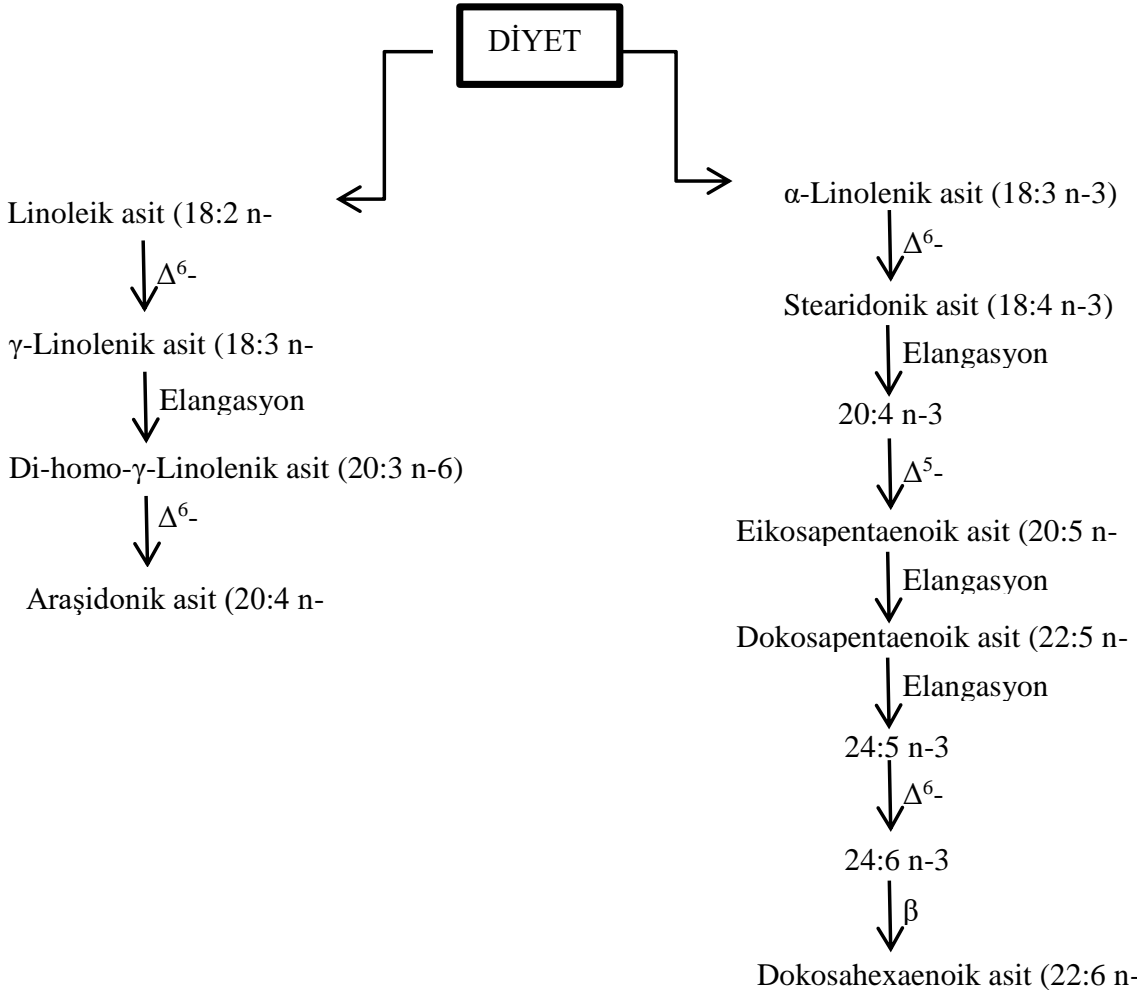

Şekil 1. Memelilerde Esansiyel Yağ Asitlerinden n-3 ve n-6 Serisi Doymamış Yağ Asitlerinin Sentezi

İnsan ve diğer memelilerin vücutlarında sentezlenemeyen ve mutlaka dışardan besinler yoluyla alınması gereken yağ asitlerine esansiyel yağ asitleri (EYA) denir. Bu yağ asitleri 18 karbonlu ve 3 çift bağ içeren $\alpha$-linolenik asit (ALA, 18:3), ve yine 18 karbon atomlu ve iki çift bağ içeren linoleik (LA, 18:2) asittir. Bunlardan linoleik yağ asidi ayçiçeği, mısır gibi pek çok bitki tohumlarında, linolenik yağ asidi ise keten ve kanola gibi bazı yağlı bitkilerin tohumlarında ve su ürünlerinde bol miktarda bulunmaktadır. İnsan ve diğer memelilerde omega-1 metil grubu ile omega-7 metil grubu karbon atomu arasında çift bağ oluşturan enzim bulunmadıği için n-3 ve n-6 serisi doymamış yağ asitlerini sentezleyemezler. Ancak LA ve ALA'nın yiyeceklerle alınması durumunda memelilerde sentezlenemeyen linoleik asitten elengasyon (karbon zincirinin uzatılması) ve desatürasyon (çift bağ sayısının arttırılması) sonucu araşidonik yağ asidi (20:4 n-6), $\alpha$-linolenik asitten ise eikosapentaenoik asit (EPA, 20:5 n-3), dokozapentaenoik asit (22:5 n-3) ve dokozahexaenoik asit (DHA, 22:6 n-3) gibi n-3 serisi yağ asitleri sentezlenebilmektedir (Şekil 1) (Du and Du, 2000; Eseceli ve ark., 2006; Haris ve ark., 2008).

Esansiyel yağ asitlerinden sentezlenen bu n-3 ve n-6 serisi uzun zincirli doymamış yağ asitlerinin organizmada pek çok fonksiyonları bulunmakla birlikte, prostoglandinlerinde ön maddelerini oluşturmaktadırlar. Prostoglandinler, hormon benzeri maddeler olup vücuttaki iltihaplanma, ağrı, ödem, tansiyon, kalp, böbrekler, sindirim sistemi, vücut sıcaklığının düzenlenmesi, alerjik reaksiyonlar, kanın pıhtılaşması ve diğer bazı hormonların yapılması gibi birçok faaliyetten sorumludurlar (Leaf ve Weber,1988). Araşidonik asit, 2. seri prostanoidler (TXA 2, PGE 2, PGI 2) ve 4. seri lökotrienlerin (LTB 4, LTC 4, LTE 4) öncü maddesi iken (bu bileşikler proenflamatuvar bileşiklerdir) EPA ve DHA ise antienflamatuvar özelliklere sahip 3. seri prostanoidler ve tromoboksanlar (TXA 3, PGE 3, PGI 3) ile 5. seri lökotrienlerin (LTB 5, LTC 5, LTE 5) öncü yağ asididir (Balçık, 2014; Konukoğlu, 2008).

\section{OMEGA-3 YAĞ ASITLERININ İNSAN SAĞLIĞI AÇISINDAN ÖNEMİ}

Son yıllarda yapılmış olan çalışmalara ait bulgular, insanların daha sağlıklı olmalarında yağların ve yağlarda bulunan yağ asitlerinin tür ve miktarlarının da önemli olduğunu göstermiştir. Günümüzde insanların gıda tüketim alışkanlıkları margarin ve kızartma yağlarının artması ile bir omega-6 yağ asidi olan ve proinflamatuvar özelliğe sahip olan eikosanoidlerin (TXA 2, PGE 2, PGI 2) ve lökotrienlerin (LTB 4, LTC 4, LTE 4) sentezinde kullanılan araşidonik asidin prekursoru linoleik 
asidin tüketiminin artmasına yol açmıştır. Oysa bir diğer omega-3 yağ asidi olan $\alpha$-linolenik asit ve onun türevleri olan ve antienflamatuvar özelliğe sahip eikosaenoidler (TXA 3, PGE 3, PGI 3) ile EPA ve DHA gibi n-3 yağ asitlerinin tüketiminin prostat, göğüs, akciğer ve bağırsak kanserlerinin önlenmesinde, kardiyovasküler hastalıklar, hipertansiyon, romatoid artrit, osteoporoz, diyabet, astım, Alzheimer, depresyon ve şizofreni gibi hastalıkların önlenmesi ve tedavisinde önemli etkiye sahip olmasının yanı sıra immün sistemin kuvvetlendirilmesi, erken dönemde zeka gelişimi, yüksek doğum ağırlı̆̆ı üzerine de çok önemli olumlu etkilerinin olduğu bildirilmektedir (Ceylan ve ark.,1999; Leskanich ve Noble 1997). Keza adı geçen yağ asitlerinin sinir sistemi gelişimi, beyin fonksiyonları ve retina üzerine de pozitif etkilerinin olduğu ifade edilmektedir (Çabuk ve ark., 1999).

Omega-3 yağ asitlerinin bu etkilerine bağlı önemi ilk defa Grönland Eskimoları üzerinde yapılan araştırmalarla ortaya konmuştur. Geleneksel gıdalar yüksek oranda yağ içermesine rağmen, Eskimolar'ın neredeyse kalp-damar hastalıklarına hiç yakalanmadıkları görülmüştür. Bunun nedeni olarak Eskimolar'ın n-3 yağ asitlerini bol miktarda içeren balık tüketmeleri olduğu ileri sürülmüş ve böylece bu konuda çalışmalar başlatılmıştır. Bucher ve ark. (2002) 1966 ile 1999 yılları arasında yapmış oldukları kapsamlı bir araştırmada, günde 40-60 gr balık tüketen gruplarda kalp damar hastalıkları ve mortalitenin önemli düzeyde azaldığını bildirmişlerdir. Keza, Marchioli ve ark. (2001) miyokardiyal enfarktüs geçirmiş hastaların diyetlerine $850 \mathrm{mg} /$ gün n-3yağ asidi ilavesinin mortalite ve tekrar miyokardiyal enfarktüs geçirme riskini azalttığını rapor etmişlerdir. Daviglus ve ark. (1997) 1822 erkek birey üzerine yürüttükleri uzun süreli bir araştırmada $35 \mathrm{gr} /$ gün balık tüketen bireylerde kardiyovasküler hastalıklara yakalanma ve miyokardiyal enfarktüs geçirme oranının hiç balık tüketmeyenlere göre \%38 daha az olduğunu ifade etmişlerdir. Yine konu ile ilgili olarak 84664 kadın üzerinde 16 yıl sürdürülen bir çalışma sonucunda, haftada bir öğün balık tüketen kadınlarda kardiyovasküler hastalıklardan ölenlerin oranının, ayda bir öğün tüketenlere göre \%29-34 daha az olduğu rapor edilmiştir (Hu ve ark., 2002).

Omega-3 yağ asitlerinin kardiyovasküler hastalıklar üzerine olan olumlu etkilerinin mekanizması tam olarak bilinmemekle birlikte bu yağ asitlerinin karaciğerde doymuş yağ asitlerinin, trigliseritlerin, lipoprotein B ve LDL'nin sentezini engelleyip oluşumunu azaltmak suretiyle, plazma HDL miktarını artırarak kolesterolün karaciğere taşınması ve orada safra asitlerine dönüşümü ve eksresyonunu sağlayarak bu etkiyi yaptığı düşünülmektedir (Dyerberg, 1986; Kinsella ve ark.,1990). Keza, omega-3 yağ asitleri karaciğerde kolesterol sentezini sağlayan 3-Dihidroksi-3-Metilglutaril CoA enziminin aktivitesini baskılayarak serum kolesterol düzeyinin düşmesinde dolayısıyla da artheroskleroz oluşumunun önlenmesi ve gecikmesinde önemli role sahiptir (Kinsella ve ark.,1990). Ayrıca diyetle alınan EPA ve DHA membranlarda araşidonik asidin yerini alarak, burada meydana gelen (TXA 3, PGE 3 ve PGI 3) ürünlerin daha az protrombik ve vazokonsriktif olması antiatheroskleratik etkileri de önem taşır (Nakamura ve ark.,1999).

Yapılan çalışmalar omega-3 yağ asitlerinin antihipertansit etkilerinin bulunduğunu göstermiş̧ir. Söz konusu yağ asitleri trombositlerde bulunan $\Delta^{6}$ desatüraz, siklooksijenaz ve lipoksijenaz enzimlerinin aktivitelerini inhibe ederek damar büzücü ve trombin oluşturucu etkiye sahip trombaksanların (TXA 2, PGE 2 ve PGI 2) sentezinde kullanılan araşidonik asidin linoleik asitten sentezini önlemek suretiyle, onun yerine damar genişletici ve antiagregasyon özelliğe sahip (TXA 3, PGE 3 ve PGI 3) bileşiklerin prekürsoru olan EPA'nın yer almasını sağlayarak trombositlerin damarlarda kümeleşme ve pıhtı oluşturmasını engeller ve kan basıncının düşmesini sağlar (Boudreu ve ark.,1991). Keza omega-3 yağ asitleri, anjiyotensin dönüştürücü enzim aktivitesini inhibe edip anjiyotensin II oluşumunu kontrol ederek kan basıncının düzenlenmesini sağlarlar (Kaergel ve ark.,2002). Ayrıca n-3 yağ asitleri uzun zincirli olmaları ve çok sayıda doymamış çift bağ içermeleri nedeniyle kanda akışkanlık sağlayarak damar içi vizikoziteyi düşürücü etkiye sahiptirler. Böylece n-3 yağ asitleri özellikle beyin kılcal damarlarında trombozun oluşumunu engelleyerek trombotik felç riskinin azalmasına neden olurlar. Nitekim Iso ve ark (2001) yaklaşık 80 bin denek kadın üzerinde 14 yıl süreyle yürüttükleri araştırmada, haftada iki öğün balık tüketen kadınların da ayda bir defa tüketenlere göre $\% 52$ daha az trombotik felç risk taşıdıklarını tespit etmişlerdir.

Omega-3 yağ asitlerinin eklemlerde şişme, ağrı, hareket zorluğu, ateş yorgunluk ve halsizlik gibi semptomlarla karakterize edilen romatoid artrit (eklem iltihabı) hastalı̆ı̆ın belirtilerinin önlenmesi, azaltılması ve tedavisinde çok önemli etkisinin olduğu bildirilmektedir. Hastalığın nedeni henüz tam olarak bilinmemekle birlikte genetik faktörler ile otoimmünite süreçleri ile bağlantıları olduğu düşünülmektedir. Omega-3 yağ asitleri artrit ve otoimmün hastalıkların belirtilerini hafifletici, doğal iltihap giderici bileşiklere sahiptir (Eseceli ve ark., 2006). Romatoid artrit hastalarına günde 2.6 gr n-3 
yağ asitleri verilerek bir yıl süreyle yürütülen çalışmada $n-3$ yağ asitlerinin hastaların durumunda iyileşme sağladığı ve ağrılarını hafiflettiği ifade edilmiştir (Geusens ve ark.,1994).

Omega-3 yağ asitlerinin organizmayı hastalıklara karşı koruyan bağışıklık sistemi üzerine olumlu etkilerinin bulunduğu bilinmektedir. Bu yağ asitleri bağışıklık sisteminin hücreleri olan organizmayı patojen bakterilere, virüslere, mantarlara, yabancı dokulara ve tümörlere karşı koruyan, antijenlere karşı antikor adı verilen özel proteinler üreten $\mathrm{T}$ ve $\mathrm{B}$ imfositler ile organizmaya zarar veren maddeleri fogositoz yoluyla ortadan kaldıran makrofajların sentezini sağlayarak organizmayı hastalıklara karşı dirençli hale getirmektedirler (Guo ve ark., 2004).

Omega-3 yağ asitlerinin özellikle gebeliğin son üç ayında ve doğumdan sonraki bebeklik döneminde beyin, retina ve sinir sistemi gelişimi üzerine çok önemli bir role sahip olduğu bildirilmektedir. Bu yağ asitlerinden özellikle DHA'nın önemli bir yeri vardır. Çünkü DHA ilgili dokuların membran yapılarında bulunan ve hücre için hayati fonksiyonlara sahip fosfolipitlerin elzem doğal bir komponentidir (Connor, 2000;Mahaffey, 2004). Ayrıca konuyla ilgili çalışmada hamilelik döneminde yeterli miktarda $\mathrm{n}-3$ yağ asitleri tüketiminin prematüre doğum riskini de azalttığı ifade edilmiştir (Olsen, 2002). Yine konuyla ilgili olarak Neuringer ve ark 1984)'nın gebe maymunları n-3 yağ asitleri bakımından noksan diyetlerle besleyerek yaptıkları çalışmalarında, bu hayvanlardan doğan bireylerde görme ve algılama azalması, elektroretinogram anormallikleri ve bazı davranış bozuklukları gibi derin değişimler görüldüğünü bildirmişlerdir.

Omega-3 yağ asitlerinin diğer bazı fizyolojik fonksiyonlarını özetleyecek olursak; n-3 yağ asitlerinin hücre membranlarının akışkanlığı üzerine de anahtar bir role sahip olduğu ve bu yağ asitlerinin eksikliğinde gelişen membran sertliği, transport fonksiyonlarını, reseptör etkileşimi ve sayılarını olumsuz yönde etkilemektedir. Örneğin membran akışkanlığındaki artış insülin reseptörlerinin sayısını artırırken membranların katılaşması bu reseptörlerin sayısında azalmaya neden olarak insülin direncine dolayısıyla diyabete yol açmaktadır (Konukoğlu, 2008). Omega-3 yağ asitlerinden EPA ve DHA beyindeki hücrelerin yenilenmesine yardımcı olarak beyin ile retina hücrelerinin çoğalmasını sağlamaktadır. Yapılan çalışmalar n-3 yağ asitleri tüketimi ile Alzheimer, şizofreni, depresyon, hafıza kaybı ve görme bozuklukları gibi problemler arasında zıt bir ilişkinin bulunduğunu göstermiştir (Canbulat ve Özcan 2008). Morris ve ark. (2003), haftada en az bir porsiyon balık tüketen bireylerde, daha seyrek tüketenlere göre Alzheimer görülme riskini \%60 oranında azalttığını ifade etmişlerdir. Keza, ilgili yağ asitlerinin antisosyal davranışlar gösteren, öğrenme güçlüğü çeken, şizofreni ve depresyona yol açan zihinsel dengesizlikleri bulunan bireylerin tedavisinde de pozitif sonuçlar verdiği bildirilmektedir (Marangell ve ark., 2003).

Omega-3 yağ asitleri mortalitesi yüksek ve bir yeni doğan hastalığı olan Necrotizan enterekolit (NEC) de rol oynayan, trombosit aktive edici faktör (PAF) ve tümör nekrozis faktör gibi inflamatuvar mediatörlerin bağırsaklardan salınımını inhibe ederek bu hastalığın oluşumunu engellerler (Coşkun,2005). Özellikle EPA Ca'un emilimini ve kemiklerde depolanmasını sağlayarak kemiklerde $\mathrm{Ca}$ yoğunluğunu yükseltir ve böylece, genellikle yaşl1lık döneminde görülen ve sıkıntılı bir problem olan osteoporoz (kemik erimesi) oluşumunu engeller. EPA bu etkiyi kemik oluşumunu baskılayan PGE 2 hormonunun salınımını engelleyerek gerçekleştirdiği ileri sürülmektedir (Watkins ve ark.,2001). Bu fonksiyonları dışında astım, migren, sedef gibi bazı cilt hastalıkları ile göğüs, prostat, akciğer ve bağırsak kanserlerinden korunmada çok önemli pozitif etkilere sahip oldukları tespit edilmiştir. Omega-3 yağ asitlerinin kanser üzerinde direk tedavi edici etkisinden çok, hastalıktan korunma ve ağrıları dindirici etkisi daha yaygın olarak görülmektedir (Gogus ve Chris, 2010).

Yapılan bazı bilimsel araştırmalar n-3 yağ asitlerinin çağımızın belki de en büyük hastalığı olan ve kalp-damar hastalıklarından, yüksek tansiyona, Alzheimer'dan felce, amfizemden uyku apnesine, cilt problemlerinden eklem problemlerine ve insülin direncine kadar onlarca hastalığın meydana gelmesine zemin hazırlayan obezitenin tedavisinde anahtar bir rol oynayacağı bildirilmektedir. Alfa linolenik asidin tüketiminin artması ile daha fazla yağ asidi oksidasyon yollarına gönderilir (Olson, 2003). Çoklu doymamış yağ asitlerinin yağ asidi oksidasyonunu sağlayan genleri aktive ettiği, yağ asitlerinin sentez ve depolanmasını sağlayan genleri baskıladığı anlaşılmıştır. Bu veriler, çoklu doymamış yağ asitlerinin, özelikle de n-3 yağ asitlerinin yakın bir gelecekte yağ asidi oksidasyonunu artırarak obezitenin tedavisinde kullanılabileceğine işaret etmektedir (Kaput, 2004). 
Çizelge 1. Omega-3 Yağ Asitlerinin Kaynakları (Konukoğlu, 2008)

\begin{tabular}{lll}
\hline Yağ Asidinin Kaynağı & $\begin{array}{l}\mathbf{1} \text { gr EPA+DHA İçin } \\
\text { Gerekli Miktar }\end{array}$ & Esansiyel Yă̆ Asidi \\
\hline Taze Tuna Balı̆̆ı & $66-357 \mathrm{gr}$ & DHA, EPA \\
\hline Konserve Tuna & $323 \mathrm{gr}$ & DHA, EPA \\
\hline Pasifik Somon & $42,5-70,9 \mathrm{gr}$ & DHA, EPA \\
\hline Sardalya & $50-87 \mathrm{gr}$ & DHA, EPA \\
\hline Alabalık & $87 \mathrm{gr}$ & DHA, EPA \\
\hline Uskumru & $54-250 \mathrm{gr}$ & DHA, EPA \\
\hline Marina Balığı & $323 \mathrm{gr}$ & DHA, EPA \\
\hline Mezgit & $417 \mathrm{gr}$ & DHA, EPA \\
\hline Pisi Balığı & $8-213 \mathrm{gr}$ & DHA, EPA \\
\hline Keten Tohumu & $2,2 \mathrm{gr} / 5 \mathrm{ml}$ & ALA \\
\hline Keten Tohumu Yağı & $8,5 \mathrm{gr} / 5 \mathrm{ml}$ & ALA \\
\hline Kenevir Yağı & $3,1 \mathrm{gr} / 5 \mathrm{ml}$ & ALA \\
\hline Kanola Yağı & $1,3 \mathrm{gr} / 5 \mathrm{ml}$ & ALA \\
\hline Soya Yağı & $0,9 \mathrm{gr} / 5 \mathrm{ml}$ & ALA \\
\hline Ceviz ve Çam Fıstığı Yağı & $0,7 \mathrm{gr} / 5 \mathrm{ml}$ & ALA \\
\hline
\end{tabular}

\section{Omega-3 Yağ Asitlerinin Muhtemel Yan Etkileri}

$\mathrm{Bu}$ yağ asitlerin diyetle günlük miktarı ve ihtiyacın (Çocuklar için 0.2-1 g/gün; yetişkinler için 1-1.5 gr/gün) düşük olması nedeniyle, bunların tüketimlerinden kaynaklanan ciddi anlamda yan etkilerinin olmadığı, keten tohumu yağında bulunan ALA'nın çok yüksek dozlarda (30 gr/gün) alınmasının ishal ve gaza neden olabileceği, ancak EPA ve DHA ile ilgili olarak herhangi bir yan etkiye rastlanılmadığ1 bildirilmektedir. Öte yandan n-3 yağ asitlerin kan vizikositesini azaltması nedeniyle, kanama riski olan kişilerin dikkatli olmaları önerilmektedir. Keza, bu yağ asitleri çok sayıda doymamış çift bağa sahip olmaları nedeniyle, oksidasyona uğrama ihtimaline karşı yüksek düzeyde kullanılmaları durumunda bunlarla birlikte diyete antioksidan maddelerin ilave edilmesi tavsiye edilmektedir (Ruxton ve ark., 2005).

\section{SONUÇ VE ÖNERILER}

Omega-3 yağ asitlerinin insan sağlı̆̆ üzerine olan etkilerinin incelendiği çok sayıdaki bilimsel araştırma bulguları, söz konusu yağ asitlerinin kalp-damar hastalıklarından yüksek tansiyona, Alzheimer'dan depresyona, romatizmal hastalıklardan astıma, immun sistem hastalıklarından osteoporoza kadar onlarca hastalığın önlenmesi ve tedavisinde önemli pozitif etkilere sahip olduklarını göstermektedir. Üstelik bu yă̆ asitleri olumlu etkilerini ciddi anlamda bir yan etki göstermeksizin doğal yolla yani beslenme ile gerçekleştirmektedir. Hâlbuki bu hastalıkların önlenmesi ve tedavisinde kullanılan ilaçların hem yüksek maliyetli hem de pek çok yan etkiye sahip oldukları bilinmektedir. Dolayısıyla yukarıda bahsedilen hastalıkların önlenmesi ve tedavisi amacıyla beslenme alışkanlıklarımızda radikal değişiklikler yapmaksızın söz konusu yağ asitlerince zenginleştirilmiş süt ürünleri ile ceviz, badem, semizotu vb. gibi yeşil sebzeleri tüketmek suretiyle doğal yolarla bunlardan yararlanabiliriz.

\section{KAYNAKLAR}

Balçık, M. G., 2014. Balıklarda Lipitler, Yağ Asitleri ve Bunların Bazı Önemli Metabolik Fonksiyonları.Yunus Araştırma Bülteni, (1) 51-61.

Boudreu, M.D., Chanmugam, P.,S, Hart, S.B., Lee, S.H., Hwang, D.H., 1991. Lack Of Dose Response By Dietary n-3 Fatty Acids at a Constant Ratio of n-3 to n-6 Fatty Acids in Suppressing Eicosanoid Biosynthesis From Arachidonic Acid. Am J Clin Nutr., 54, 111-117.

Brossard, N., Croset, M., Pachiaudi, C., Riou, J.P., Tayot, J.L., Lagarde, M., 1996. Retroconversion And Metabolism of [13C] 22:6n-3 in Humans and Rats After İntake of a Single Dose of [13C] 22:6n-3Triacylglycerols. Am. J. Clin. Nutr., 64, 577-586.

Bucher, H.C., Hengstler, P., Schindler, C., Meier, G., 2002. N-3 Polyunsaturated Fatty Acids in Coronary Heart Disease: a Meta-Analysis Of Randomized Controlled Trials. Am. J. Med., 112, 298-304.

Canbulat, Z. ve Özcan, T., 2008. Süt Ürünlerinin EPA ve DHA İle Zenginleştirilmesi. Türkiye 10. Gıda Kongresi, 21-23 Mayıs; 713-716. 
Ceylan, N., Yenice, E., Gökçeyrek, D., Tuncer, E., 1999. İnsan Beslenmesinde Daha Sağlıklı Yumurta Üretimi Yönünde Kanatlı Besleme Çalışmaları. YUTAV'99 Uluslararası Tavukçuluk Fuarı ve Konferansı, 3-6 Haziran, İstanbul, 300-307.

Connor, W.E., 2000. Importance Of N-3 Fatty Acids in Health and Disease. Am. J. Clin. Nutr., 71, 1715-1755.

Coşkun, T., 2005. Fonksiyonel Besinlerin Sağlımız Üzerine Etkileri. Çocuk Sağlığı ve Hastalıkları Dergisi, 48, 69-84.

Çabuk, M., Ergül, M., Basmacioğlu, H., Akkan, S., 1999. Yumurta Ve Piliç Etindeki N-3 Yağ Asitlerinin Artırılma Olanakları. Uluslararası Hayvancılık 99 Kongresi, 224-24 Eylül, İzmir.

Çakmakçı, S. ve Kahyaoğlu, D.T., 2012. Yağ Asitlerinin Sağlık ve Beslenme Üzerine Etkileri. Türk Bilimsel Derlemeler Dergisi; 5, 133-137.

Çelebi, Ş. ve Karaca, H., 2006. Yumurtanın Besin Değeri, Kolesterol İçeriği ve Yumurtayı N-3 Yağ Asitleri Bakımından Zenginleştirmeye Yönelik Çalışmalar. Atatürk Üniversitesi Ziraat Fakültesi Dergisi, 37, 257-265.

Das, U.N., 2006. Essential Fatty Acids: Biochemistry, Physiology and Pathology. Biotechnol., 420-439.

Daviglus, M.L., Stamler, J., Orencia, A.J., Dyer, A.R., Liu, K., Greenland, P., Walsh, M.K., Morris, D., Shekelle, R.B., 1997.Fish Consumption and The 30-Year Risk of Fatal Myocardial İnfarction. the New England Journal of Medicine, 1046-1053.

Du, M., Ahn, D.U., Sell, J.L., 2000. Effects of Dietary Conjugated Linoleic Acid and Linoleic:Linolenic Acid Ratio on Polyunsaturated Fatty Acid Status in Laying hens. Poultry Sci., 79, 1749-1756.

Dyerberg, J., 1986. Linolenate-Derived Polyunsaturated Fatty Acids and Prevention of Atherosclerosis. Nutr. Rev., 44, 125-135.

Eseceli, H., Değirmencioğlu, A., Kahraman, R., 2006. Omega Yağ Asitlerinin İnsan Sağlı̆̆ı Yönünden Önemi. Türkiye 9. Gida Kongresi, 24-26 Mayıs, Bolu, 403-406.

Geusens, P., Wouters, C., Nijs, J., Jiang, Y., Degueker, J., 1994. Long-Term Effect of Omega-3 Fatty Acid Supplementation in Active Rheumatoid Arthritis. A 12-Month, Double-Blind, Controlled Study. Arthritis Rheum., 37, 824-829.

Gogus, U. ve Chris, S., 2010. n-3 Omega Fatty Acids: a Review of Current Knowledge. International Journal of Food Science and Technology, 45, 417-436.

Guo, Y., Shiyong, C., Xia, Z., Yuan, J., 2004. Effects of Different Types of Polyunsaturated Fatty Acids on İmmune Function and PGE2 Synthesis By Peripheral Blood Leukocytes of Laying Hens. Animal Feed Science and Technology, 116, 249-258.

Harris, W.S., Miller, M., Tiqhe, A.P., Davidson, M.H., Schaefer, E.J., 2008. Omega-3 Fatty Acids and Coronary Heart Disease Risk: Clinical and Mechanistic Perspectives. Atherosclerosis, 197, 12-24.

Hu, F.B., Bronner, L., Willet, W.C., Stampfer, M.J., Rexrode, K.M., Albert, C.M., Hunter, D., Manson, J.E., 2002. Fish and Omega-3 Fatty Acid İntake and Risk of Coronary Heart Disease in Women. JAMA, 287, 1815-1821.

Iso, H., Rexrode, K.M., Stampfer, M.J., Manson, J.E., Colditz, G.A., Speizer, F.E., Hennekens, C.H., Willett, W.C., 2001. Intake of Fish and Omega-3 Fatty Acids and Risk of Stroke in Women. JAMA, 285, 304312.

Kaergel, E., Muller, D.N., Honeck, H., Theuer, J., Shagdarsuren, E., Mullally, A., Luft, F.C., Schunck, W.H., 2002. P450-dependent Arachidonic Acid Metabolism and Angiotensin II-İnduced Renal Damage. Hypertension, 40, 273-279.

Kaput, K., 2004. Diet-Disease Gene İnteractions. Nutrition, 20, 26-31.

Karaca, E. ve Aytaç, S., 2007.Yağ Bitkilerinde Yağ Asitleri Kompozisyonu Üzerine Etki Eden Faktörler. Ondokuz Mayıs Üniversitesi Ziraat Fakültesi Dergisi, 2, 123-131.

Keha, E. ve Küfrevioğlu, İ., 1993. Biyokimya. Derya Kitapevi. Trabzon.sayfa sayıs1

Kinsella, J.E., Lokesh, B., Stone, R.A., 1990. Dietary n-3 Polyunsaturated Fatty Acids and Amelioration of Cardiovascular Disease: Possible Mechanisms. Am. J. Clin. Nutr., 52, 1-28.

Konukoğlu, D., 2008. hastalıklar ile ilişkileri Omega-3 ve omega-6 yağ asitlerinin özellikleri, etkileri ve kardiyovasküler. Türk Aile Hek. Derg., 2, 121-129.

Leaf, A. ve Weber, P.C., 1988. Cardiovascular Effects Of n-3 Fatty Acids. N. Engl. J. Med., 318, 549-557.

Leskanich, C.O. ve Noble, R., 1997.Manipulation of The n-3 Polyunsaturated Fatty Acid Composition of Avian Eggs and Meat. World's Poultry Science Journal, 53, 155-183.

Mahaffey, K.R., 2004. Fish and Shellfish as Dietary Sources of Methylmercury and the Omega-3 Fatty Acids, Eicosahexaenoic Acid and Docosahexaenoic Acid: Risks and Benefits. Environ. Res., 95, 414-428.

Marangell, B.L.B., Martinez, J.M., Zboyan, H.A., Kertz, B., Kim, H.F., Puryear, L.J., 2003. A Double-Blind, Placebo-Controlled Study of the Omega-3 Fatty Acid Docosahexaenoic Acid in The Treatment of Major Depression. Am. J. Psychiatry., 160, 996-998.

Marchioli, R., Schweiger, C., Tavazzi, L., Valaqussa, F., 2001. Efficacy of n-3 Polyunsaturated Fatty Acids After Myocardial İnfarction: Results of GISSI-Prevenzione Trial. Gruppo Italiano Per Lo Studio Della Sopravvivenza Nell'infarto Miocardico. Lipids, Suppl., 119-126.

Morris, M.C., Evans, D.A., Bienias, J.L., Tangney, C.C., Bennett, D.A., Wilson, R.S., Aqqardwal, N., Schneider, J., 2003. Consumption of Fish and n-3 Fatty Acids and Risk of İncident Alzheimer Disease. Arch. Neurol., 60, 940-946. 
Nakamura, N., Hamazaki, T., Ohta, M., Urakaze, M., Sawazaki, S., Yamazaki, K., Satoh, A., Temaru, R., Ishikura, Y., Takata, M., Kishida, M., Kobayashi, M., 1999. Joint Effects of HMG-Coa Reductase İnhibitors and Eicosapentaenoic Acids on Serum Lipid Profile and Plasma Fatty Acid Concentrations in Patients With Hyperlipidemia. Int. J. Clin. Lab. Res., 29, 22-25.

Neuringer, M., Connor, W.E., Van Petten, C., Barstad, L., 1984. Dietary Omega-3 Fatty Acid Deficiency and Visual Loss in İnfant Rhesus Monkeys. J. Clin. Invest., 73, 272-276.

Olsen, S.H., 2002. Low Consumption of Seafood in Early Pregnancy as a Risk Factor For Preterm Delivery: Prospective Cohort Study. British Med. J., 23, 1447-1450.

Olson, R.E., 2003. Nutrition and Genetics: An Expanding Frontier. Am. J. Clin. Nutr., 78, 201-208.

Ruxton, C.H.S., Calder, P.C., Reed, S.C., Simpson, M.J.A., 2005. The İmpact of Long Chain n-3 Polyunsaturated Fatty Acids on Human Health. Nutrition Research Reviews, 18, 113-129.

Watkins, B.A., Li, Y., Lippman, H.E., Seifert, M.F., 2001. Omega-3 Polyunsaturated Fatty Acids and Skeletal Health. Exp. Biol. Med. 226, 485-497. 